\title{
Energy saving as a necessary condition for the development of a green economy in the context of globalization and transformation of society
}

\author{
Yulia Vertakova ${ }^{1, *}$, Olga Kryzhanovskaya ${ }^{1}$ \\ ${ }^{1}$ South-West State University, Department of Regional Economics and Management, 305040, 94, 50 \\ let Oktyabrya str., Kursk, Russia
}

\begin{abstract}
.
Research background: The world is actively transforming socio-economic and production processes. Ensuring economic growth today is accompanied by an increase in living standards and environmental degradation, the exhaustion of natural resources, imbalance in the biosphere, and climate change, which leads to poor human health and limits the possibilities for further development. All this is due to the need to transform both the provision of technological progress for economic development, and the favouring of the natural environment in the context of globalization.

Purpose of the article: The purpose of the article is to study energy conservation as a necessary condition for the development of a "green" economy in the context of globalization and transformation of society.

Methods: The research is based on general scientific methods of empirical research (observation, measurement, experiment, modelling), analysis and synthesis, analogy, systematization, as well as methods of structural-logical, statistical analysis.

Findings \& Value added: The article systematizes approaches to defining the concept of a green economy, reveals the relationship between the categories of politics and society, and elements of the green economy. The efficiency of the use of fuel and energy resources is determined by the energy intensity of GDP. In this regard, the predicted dynamics of energy intensity of GDP by regions of the world, energy consumption per capita in the world and groups of countries are analysed, measures of state support in the field of energy conservation and energy efficiency are substantiated.
\end{abstract}

Keywords: energy conservation; energy efficiency; green economy; transformation.

JEL Classification: F63; $Q 43 ; Q 48$

\footnotetext{
${ }^{*}$ Corresponding author: vertakova7@yandex.ru
} 


\section{Introduction}

Ensuring economic growth today is associated with environmental pollution and deterioration of natural resources, imbalance in the biosphere, climate change, which leads to a deterioration of human health and limits development opportunities. This means that solving the important problem of improving the well-being of the population does not provide the required quality of life.

All this determines the essence of modernization as ensuring technological progress for economic development and maintaining a favorable natural environment (environmental safety, which becomes decisive for economic growth and human existence itself). This task is voiced in the world as the implementation of the principle of "decoupling" (meeting growing needs while minimizing the depletion of natural capital), which implies a decrease in energy intensity and nature intensity in general economic growth, widespread use of renewable energy sources, modernization of production based on innovation. This direction determines the priorities of the country's economic development today. According to the UNEP reports (United Nations Environment Program) [1], a green economy is defined as an economy that enhances human well-being and social justice.

Thus, it is necessary to study the prospects for the development of a green economy, as well as the possibility of improving the quality of life and modernizing existing production.

In the context of globalization and transformation, the whole world faces many new "challenges". Related to this is the need to modernize the economy, including innovative development and energy efficiency. The main goal of all measures aimed at modernizing the economy is to improve the living conditions of every person today and to ensure favorable conditions for future generations. One of the newest models of economic development as a response to the challenge of natural and economic global transformation was formulated in 1992 in Rio de Janeiro at the World Conference on Environmental Development. It is called sustainable development. The essence of sustainable development is to ensure such economic growth, which makes it possible to harmonize the relationship "man-nature (environment)" and preserve the natural environment for current and future generations. Many countries are actively developing long-term programs within the framework of the concept of sustainable development. At the same time, an urgent task is to identify the main problems associated with the development of cities, energy, water, food and ecosystems, as well as the formation of principles and methods of state regulation of these processes. This task is defined as ensuring sustainable development based on the principles of the green economy [2].

The problem of the emergence and development of the green economy dates back to the 70 s XX century. Scientists all over the world wrote about the need for a new format of the economy in the context of the development of world industry. One of the first was Frances Moore Lappé, an American researcher and author in the field of food and democratic policy ("Diet for a Small Planet"), where it was stated that world hunger is caused not by food shortages, but by ineffective food policies, as well as by inefficient distribution of money and energy resources. In 2012 she also published an article "Our Challenge - Developing an EcoMind" in the scientific journal "Green economy in action", in which she pointed out the importance of developing eco-thinking among people around the world, because the green economy simply cannot survive in the face of growing goods - and energy consumption [3]. Jeremy Rifkin in his book "The Third Industrial Revolution" says that now fundamental economic changes are taking place in conjunction with the introduction of elements of the green economy [4]. Molly Scott Kato, British green politician, academic, environmental and social activist, argues that the world as we know it needs a new economy. Climate change, financial crisis and uncontrolled globalization are all major problems, rooted in the dominant economic system. The green economy argues that society must be embedded in the ecosystem, and markets and the economy as a whole must respond to rapidly emerging and 
changing social and environmental priorities [5]. Among the Russian scientists studying the problems of the green economy, as well as the problems of energy conservation as a necessary condition for the development of the green economy, one can name Vertakova $\mathrm{Yu}$. [6], Plotnikov V. [7], Babich T. [8], Zlobina N., Merkulova E., Muratova O. [9], Kondrakov O.,etc.

\section{Methods}

The United Nations Environment Program "Towards a Green Economy" synthesis report for policymakers sees a green economy as an economy that enhances human well-being and social justice, while significantly reducing environmental risks and impoverishment. It is a low carbon, resource efficient and socially inclusive economy.

In the annual UNEP-2009 report, a green economy is "a system of economic activities related to the production, distribution and consumption of goods and services that leads to improved human well-being in the long term, without exposing future generations to significant environmental risks or environmental deficits.

The South African Government Strategy notes that a green economy is one that includes new economic activities. It should be the starting point for broad participation of the black majority in the economy, and should also meet the needs of women, youth, and entrepreneurs and open up opportunities for entrepreneurship in the social economy.

The second session of the UN Preparatory Committee for the Conference on Sustainable Development on March 7-8, 2011 sees the green economy as a concept that brings together a set of measures to attract investment in environmentally significant industries that contribute to sustainable development and poverty eradication.

Thus, a green economy is described as an economy in which economic growth and environmental responsibility mutually reinforce each other, while supporting progress in social development. The terms «green economy», «green growth» and «low-carbon development» are often used interchangeably and are applied in different contexts to different industries, resources, areas, and even concepts. The main driving force behind the development of the latter was the development of an integrated and holistic approach to integrating environmental issues into the spheres of economic policy and planning. The relationship between different categories of politics and society, as well as elements of a green economy (green growth, green taxes and accounts, green innovation, a green new deal) are shown in Fig. 1.

Based on the above, it can be concluded that the green economy not only values natural capital, but also invests in it. The green economy is replacing fossil fuels with clean energy and low-carbon technologies, reducing climate impacts while creating decent jobs and reducing import dependency. New technologies that drive energy and resource efficiency are opening up opportunities for growth in new directions, compensating job losses in the brown economy. Improving resource efficiency - the efficiency of using both electricity and raw materials - is manifested everywhere, including in improving the waste management system, strengthening the role of public transport, green building and reducing food waste along the entire food production and consumption chain.

The research is based on general scientific methods of empirical research (observation, measurement, experiment, modelling), analysis and synthesis, analogy, systematization, as well as methods of structural-logical, statistical analysis. 


\section{Results and discussions}

Energy problems have always been at the center of increased public attention. Energy production in the world is constantly growing, doubling every 5-7 years. Modern energy is $80 \%$ fuel that means it uses fossil carbon fuels. Thermal waste from such energy is considered the most dangerous for the biosphere and humanity. The energy sector must ensure the safe use of traditional types of resources and increase energy efficiency. The 2011 United Nations General Assembly launched the "Sustainable Energy for All" initiative. This initiative is addressed to business, governments, investors, communities, and academia and aims to achieve three main goals by 2030: ensuring universal access to modern energy services; reducing the intensity of global energy consumption by $40 \%$; increasing the share of renewable energy sources in the world up to $30 \%$.

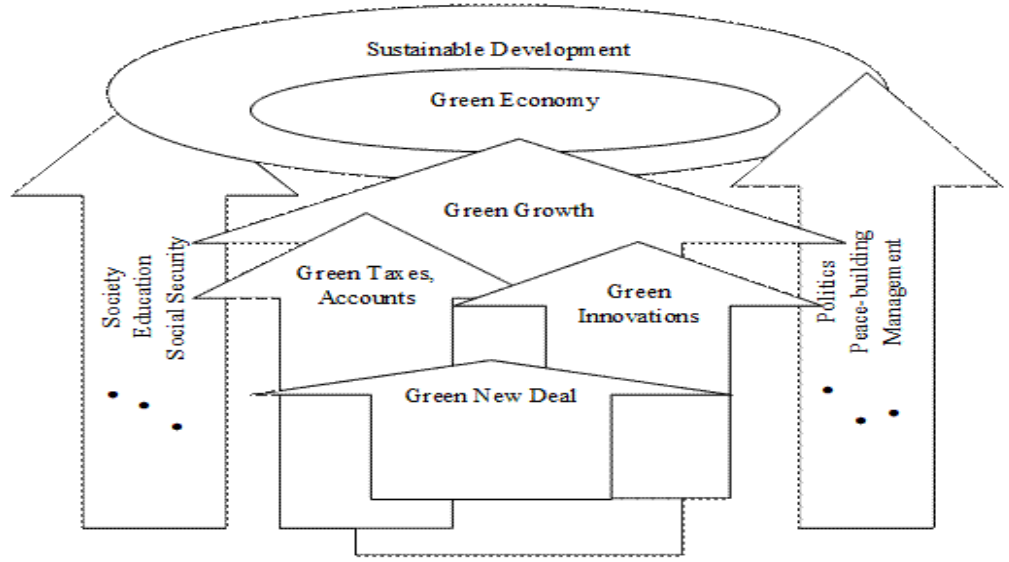

Fig. 1. Elements of the Green Economy

Source: Compiled by the authors

At the end of 2012 a resolution was adopted declaring 2014-2024 a Decade of Sustainable Energy for All. The UN General Assembly has developed recommendations to governments to create favorable conditions for the promotion and use of new and renewable energy sources and more efficient energy consumption. The energy sector can become a major one in the transition to a green economy. The Covid-19 pandemic is a global crisis. As a result of restrictions imposed in many countries to slow the spread of the virus, the share of energy consumption has changed significantly (Table 1).

In the first quarter of 2020 , global energy demand declined by $3.8 \%$, with most of the impacts being felt in March when restrictive measures were introduced in Europe, North America and other countries. Global demand for coal was hit hardest, falling nearly $8 \%$ from the first quarter of 2019. Oil demand was also hit hard, falling nearly 5\% in the first quarter, mainly due to declines in mobility and aviation, which account for nearly $60 \%$ of global oil demand. By the end of March, global road traffic activity was almost 50\% below the 2019 average, and aviation was $60 \%$ below. The demand for electricity was significantly reduced (by $20 \%$ ) as a result of restrictive measures, which negatively affected the balance of electricity (the share of supplied renewable energy sources increased significantly). The demand fell for all other sources: gas and nuclear energy, except for renewable sources (the latter became the only object of growth in demand). However, the pandemic had the least impact on gas - the drop in demand for this type of fuel was the smallest - about $2 \%$. The International Energy Agency expects a further drop in global gas demand to 4-6\%. This is a 
very significant change, given that the last sharp drop in global gas demand was recorded in 2009 , when it fell by $2 \%$ [10].

Table 1. Demand for various types of energy in the world 2015-2020

\begin{tabular}{|l|c|c|c|c|c|c|}
\hline \multicolumn{1}{|c|}{ World } & $\mathbf{2 0 1 5}$ & $\mathbf{2 0 1 6}$ & $\mathbf{2 0 1 7}$ & $\mathbf{2 0 1 8}$ & $\mathbf{2 0 1 9}$ & $\mathbf{2 0 2 0}$ \\
\hline Total (billion \$) & 2063 & 1928 & 1912 & 1905 & 1891 & 1520 \\
\hline Supply (by type) & 1793 & 1634 & 1632 & 1624 & 1611 & 1273 \\
\hline $\begin{array}{l}\text { Fossil fuels (fuel and } \\
\text { electricity supply) }\end{array}$ & 1150 & 972 & 978 & 975 & 976 & 699 \\
\hline Renewable energy sources & 317 & 321 & 319 & 317 & 319 & 288 \\
\hline Power grids & 296 & 306 & 298 & 294 & 273 & 248 \\
\hline Others & 31 & 35 & 37 & 37 & 43 & 39 \\
\hline Fuel (total) & 1009 & 835 & 850 & 854 & 854 & 595 \\
\hline Fossil fuel & 1000 & 826 & 841 & 845 & 846 & 588 \\
\hline Oil & 553 & 441 & 462 & 477 & 470 & 325 \\
\hline Gas & 338 & 293 & 295 & 290 & 286 & 186 \\
\hline Coal & 109 & 92 & 84 & 78 & 90 & 76 \\
\hline Liquid biofuel and biogas & 9 & 9 & 9 & 9 & 8 & 7 \\
\hline Energy (total) & 784 & 799 & 782 & 769 & 757 & 678 \\
\hline Coal & 75 & 68 & 63 & 60 & 57 & 50 \\
\hline Gas and oil & 74 & 78 & 74 & 70 & 74 & 61 \\
\hline Nuclear energy & 29 & 33 & 34 & 33 & 39 & 35 \\
\hline Renewable energy sources & 308 & 312 & 310 & 308 & 311 & 281 \\
\hline
\end{tabular}

The baseline forecast for 2020 is a large-scale global recession caused by long-term restrictions on mobility and socioeconomic activity. With the gradual reopening of currently isolated economies, the recovery is U-shaped and accompanied by a significant permanent loss of economic activity. The global gross domestic product (GDP) is projected to decline by $6 \%$ in 2020 , the highest percentage in 70 years and the highest ever recorded in absolute terms. The impact of Covid 19 on energy demand in 2020 will be more than seven times greater than the impact of the 2008 financial crisis on global energy demand.

Global CO2 emissions are expected to decline by $8 \%$, or nearly 2.6 gigatons (GT), which is equal to 10 years ago level. This annual reduction will be the largest ever; six times more than the previous record of 0.4 GT reduction in 2009 caused by the global financial crisis, and double the cumulative sum of all previous reductions since the end of World War II. However, as in previous crises, the rebound in emissions may be greater than the recession, unless the wave of investment to restart the economy is directed towards cleaner and more sustainable energy infrastructure [11].

Thus, the pandemic has made "its own" adjustments to the global economy, challenging all energy sectors. One can only hope that its consequences will not be as dire as the World Economic Agency predicts.

Therefore, the energy component of the final product began to play a dominant role, as a result of which the problem of efficient use of energy has become one of the top priorities. The efficiency of using fuel and energy resources (FER) is determined by the energy intensity of GDP, which is used to assess the energy efficiency of national economies. Energy intensity of GDP determines the unit costs of fuel and energy resources per unit of manufactured products - it is a generalized indicator of the level of consumption of energy resources per unit of GDP. Usually, the energy intensity of GDP is considered as the ratio of the gross consumption of fuel and energy resources to the volume of GDP. This means that the higher the energy intensity in a country, the lower the energy efficiency.

†EA - International Energy Agency https://www.iea.org/ 
Figure 2 shows the forecast dynamics of GDP by regions of the world. The figure shows the principle of the development of scientific and technological progress, which consists in a gradual reduction in the cost of new technologies, as well as in maintaining the existing trends in reducing the energy intensity of the GDP of countries and regions with a tendency towards their convergence by the end of the forecast period. The absence of particularly significant technological revolutions and breakthroughs is assumed. Energy intensity is projected to decrease by $44 \%$ for the period from 2014 to 2040 . For the world as a whole, the projected energy intensity of GDP for 2040 is 0.09 toe / thousand dollars [12].

Another equally important task of the world energy sector is to reduce the level of energy consumption. Forecasting energy consumption is based on the methodology, which consists in the mutual agreement of the dynamics of consumption by countries, obtained by the "demographic method" (in terms of population and per capita energy consumption, which has multidirectional dynamics in the OECD countries, which will demonstrate a decrease in per capita energy consumption, while China and others developing countries, on the contrary, will increase this indicator (Fig. 2) using the "economic method" (based on GDP per capita and GDP energy intensity).

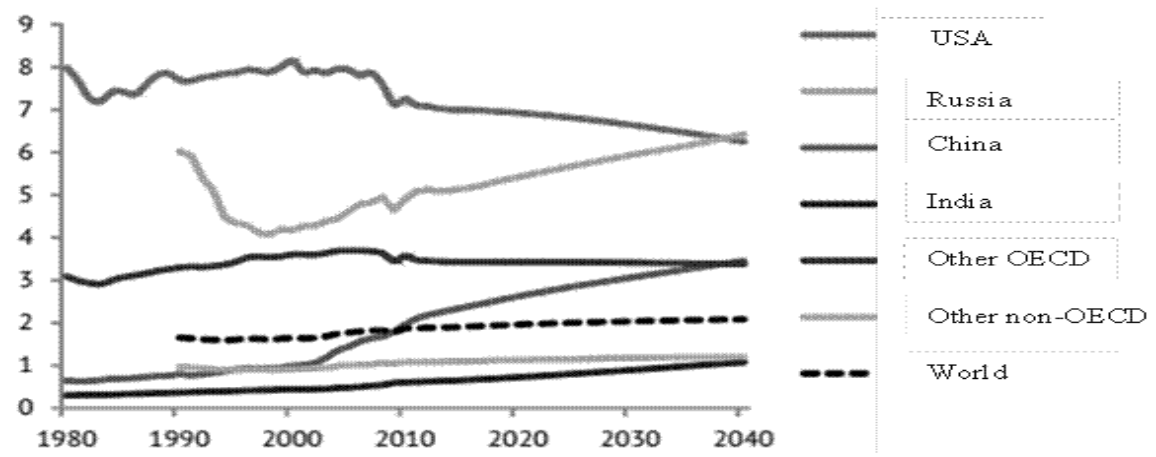

Fig. 2. Energy consumption per capita by world and country groups, Base scenario*

The forecast of primary energy consumption in the world obtained in this way in 20102040 shows an increase of $46 \%$ (or an average of $1.3 \%$ annually). The distribution of energy consumption in the world is changing noticeably: with the growth of the population in developing countries, there is an increasingly active shift there of economic growth and energy consumption centers. And developed countries, due to active energy conservation, will increase their consumption by only $4.6 \%$ by 2040 , while all this growth will take place until 2030, and then the growth in energy demand in the OECD will practically stop [12].

$\$$ Forecast of energy development in the world and Russia until 2040 https://www.eriras.ru/files/forecast_2040.pdf 
Table 2. Primary Energy Consumption by Regions of the World, Base Scenario ${ }^{\S}$

\begin{tabular}{|l|c|c|c|c|c|c|c|c|c|c|}
\hline & \multicolumn{9}{|c|}{ Consumption of primary energy resources, million } & \multicolumn{2}{|c|}{$\begin{array}{c}\text { Energy consumption } \\
\text { growth rates, \% }\end{array}$} \\
& $\mathbf{2 0 1 0}$ & $\mathbf{2 0 1 2}$ & $\mathbf{2 0 2 0}$ & $\mathbf{2 0 2 5}$ & $\mathbf{2 0 3 0}$ & $\mathbf{2 0 3 5}$ & $\mathbf{2 0 4 0}$ & $\begin{array}{c}\mathbf{2 0 1 0}- \\
\mathbf{2 0 2 0}\end{array}$ & $\begin{array}{c}\mathbf{2 0 1 0} \\
\mathbf{2 0 3 0}\end{array}$ & $\begin{array}{c}\mathbf{2 0 1 0} \\
\mathbf{2 0 4 0}\end{array}$ \\
\cline { 2 - 13 } & & & & & & & & 0,5 & 0,4 & 0,3 \\
\hline North America & 2699 & 2738 & 2832 & 2901 & 2947 & 2966 & 2964 & 0,5 & 0,3 & 0,2 \\
\hline USA & 2261 & 2273 & 2340 & 2385 & 2409 & 2411 & 2395 & 0,3 & 0,3 \\
\hline Europe & 2020 & 1956 & 1983 & 2003 & 2014 & 2018 & $2016-$ & $-0,2$ & 0,0 & 0,0 \\
\hline EU-28 & 1814 & 1731 & 1741 & 1743 & 1737 & 1725 & 1708 & $-0,4$ & $-0,2$ & $-0,2$ \\
\hline Developed Asia & 918 & 900 & 910 & 913 & 908 & 897 & 880 & $-0,1$ & $-0,1$ & $-0,1$ \\
\hline Japan & 509 & 462 & 445 & 426 & 405 & 384 & 362 & $-1,3$ & $-1,1$ & $-1,1$ \\
\hline CIS & 1047 & 1094 & 1150 & 1201 & 1239 & 1271 & 13080 & 0,9 & 0,8 & 0,7 \\
\hline Russia & 718 & 752 & 789 & 822 & 845 & 866 & 892 & 0,9 & 0,8 & 0,7 \\
\hline $\begin{array}{l}\text { Developing } \\
\text { Asia }\end{array}$ & 4187 & 5021 & 5744 & 6402 & 7008 & 7577 & 8094 & 3,2 & 2,6 & 2,2 \\
\hline China & 2676 & 3309 & 3775 & 4157 & 4473 & 4751 & 4985 & 3,5 & 2,6 & 2,1 \\
\hline India & 727 & 835 & 977 & 1137 & 1313 & 1497 & 1681 & 3,0 & 3,0 & 2,8 \\
\hline $\begin{array}{l}\text { South and } \\
\text { Central } \\
\text { America }\end{array}$ & 637 & 695 & 767 & 840 & 912 & 981 & 1047 & 1,9 & 1,8 & 1,7 \\
\hline Brazil & & & & & & & & & & \\
\hline Middle East & 269 & 295 & 330 & 366 & 403 & 439 & 476 & 2,1 & 2,0 & 1,9 \\
\hline Africa & 704 & 766 & 856 & 941 & 1020 & 1097 & 1172 & 2,1 & 1,9 & 1,7 \\
\hline World & 789 & 887 & 993 & 1103 & 1217 & 1334 & 2,3 & 2,3 & 2,2 \\
\hline
\end{tabular}

In general, according to the table, it is seen that in many regions of the world a decrease in the volume of consumed primary energy is predicted. This demonstrates the effectiveness of the measures taken to develop the energy saving sphere. Thus, the strategic goal of energy conservation is to reduce energy intensity and increase the energy efficiency of the national economy to the level of developed countries of the world. A prerequisite for this is the use of approaches to energy conservation approved in advanced countries. The energy conservation policy, proceeding consistently, allows freeing up significant resources in the national economy, since the measures taken to implement it require relatively small costs. For a successful transition to a green economy, every country needs to create an enabling environment and adequate funding, however both are achievable. Green economy can deliver the same growth and employment as brown economy in the medium to long term, while delivering more environmental and social benefits [13]. Thus, the transition to a green economy will require the concerted efforts of world leaders, civil society and leading companies. A sustained effort will be required from politicians and their electorate to rethink and redefine traditional measures of wealth, prosperity and well-being. However, the biggest risk today is the risk of maintaining the status quo. These issues are institutionalized in various countries of the world (Table 3 ).

$\S$ Forecast of energy development in the world and Russia until 2040 https://www.eriras.ru/files/forecast_2040.pdf 
Table 3. Examples of institutional consolidation of the green economy principles

\begin{tabular}{|c|c|}
\hline $\begin{array}{l}\text { Country (group } \\
\text { of countries) }\end{array}$ & Measures \\
\hline $\mathrm{EU}$ & $\begin{array}{l}\text { In } 2008 \text {, the EU Renewable Energy Directive was adopted. It provides for an } \\
\text { increase in the share of renewable energy sources in the total volume of } \\
\text { electricity production by } 2020 \text { from the current } 7.8 \% \text { to } 20 \% \text {; }\end{array}$ \\
\hline USA & $\begin{array}{l}\text { The American Recovery and Reinvestment Act of } 2009 \text { provides for an increase } \\
\text { in this indicator from } 3.1 \% \text { in } 2007 \text { to } 10 \% \text { in } 2012 \text { and up to } 25 \% \text { in } 2020 \text {. }\end{array}$ \\
\hline Brazil & $\begin{array}{l}2 / 3 \text { of renewable energy comes from biomass, which is used to produce ethanol, } \\
\text { which covers } 40 \% \text { of the demand for motor fuel, and } 1 / 3 \text { from hydroelectric } \\
\text { power plants, which are the basis of the national electricity industry (almost } \\
76 \% \text { of electricity production). Brazil's National Policy on Climate Change } \\
\text { (Law } 12.187 \text { / 2009) envisages further accelerated development of low-carbon } \\
\text { energy and economy in the period up to } 2030 \text {, including an increase in ethanol } \\
\text { production and export. }\end{array}$ \\
\hline India & $\begin{array}{l}\text { Taxes on cleantech components have been abolished and the intention to set } \\
\text { fines for delays in solar installation has been officially announced. }\end{array}$ \\
\hline China & $\begin{array}{l}\text { The government has achieved production from renewable sources (excluding } \\
\text { hydroelectric power plants) } 3 \% \text { of electricity in } 2010 \text {, and by } 2020 \text { the goal is to } \\
\text { bring this figure to } 8 \% \text {. In accordance with the XII Five-Year Development Plan } \\
\text { of the country, the energy intensity of GDP should decrease in } 2020 \text { - by } 40- \\
45 \% \text {, and in } 2050 \text { - by } 60-68 \% \text {. }\end{array}$ \\
\hline
\end{tabular}

\section{Conclusion}

There are very clear differences in approaches to energy conservation in different countries, associated with the peculiarities of the national mentality, cultural preferences and prevailing stereotypes of behavior. However, an important common feature of the developed countries is the policy focus on achieving energy savings at the energy use stage.

The US economy is 2.5 times more energy efficient than the Russian economy. According to some experts, the production of manufactured goods in America consumes 9 times less energy than in Russia. Currently, the level of energy consumed in the country for the production of goods and services in the amount of $\$ 1$, has decreased by more than $50 \%$ compared to 1970. The American energy efficiency achievement is the result of years of energy conservation efforts. A feature of the US energy efficiency policy is the widespread use of various measures of financial incentives and the evasion of the adoption of all kinds of codes and regulations. That means that the main efforts are directed not at coercion, but at interest. Recognizing the opportunities offered by energy efficiency, more than 60 leading organizations representing various stakeholders across the country joined forces in 2006 to develop a National Energy Efficiency Action Plan. Many of these stakeholders are precisely the groups that can provide energy savings - power and gas utilities, state regulators, and other organizations.

The action plan identifies the main barriers to investment in energy efficiency. It outlines five key recommendations for achieving the goal of cost-effective energy efficiency. The plan also provides the foundations of the "Outlook 2025" strategy, which provides for actions to achieve and evaluate progressive development towards the set goal. The main goals of the state policy to improve energy efficiency:

- reduce US dependence on oil imports;

- develop and introduce energy-saving technologies for public buildings, residential buildings, transport, energy and industrial sectors.

- attract investments in developments to improve energy efficiency with high implementation risks; 
- promote the introduction of clean energy technologies and practices;

- promote the production of energy efficient machinery and equipment with low environmental pollution;

- reduce the cost of building energy efficient houses;

- help the low-income groups to reduce energy costs;

- maintain the reliability of energy transport communications.

At the same time, activities in the directions chosen by the state should be beneficial to the population and business due to state preferences; the state should provide detailed information to the population and business about the goals and priorities of increasing energy efficiency, as well as about the conditions for obtaining state support in activities in priority areas.

In Japan, after the first oil crisis, energy conservation measures were taken, which led to a $35 \%$ decrease in the energy intensity of the gross national product by 1985 . However, then, over 7 years, energy consumption increased by an average of $3.1 \%$ per year. Therefore, the Japanese government revised the Energy Rational Use Law in 1993. Under the revised law, the Ministry of Economy, Trade and Industry of Japan (METI) is to establish and declare the basic principles of policy aimed at comprehensively promoting the rational use of energy, and the main consumers should make efforts to rationalize the use of energy in accordance with this policy.

The Law "On Rational Use of Energy" includes 3 principles:

- ensuring energy security, which includes measures to save resources, diversify the supply of imported energy resources and develop relations with the main exporting countries, increase self-sufficiency in energy, create strategic reserves of oil, oil products and natural gas;

- ensuring environmental protection, including measures to reduce greenhouse gas emissions, increase the use of alternative energy sources, develop and introduce resourcesaving and energy-efficient technologies;

implementation of energy policy based on market mechanisms.

By setting a $30 \%$ increase in energy efficiency by 2030 over 2006, the Japanese government is committed to ensuring a modern energy supply / demand structure in a market with the high prices expected by the government in the medium to long term. In April 2009, the Government of Japan, relying on the strategy of economic development and measures to overcome the economic crisis, approved a concept to reduce $\mathrm{CO} 2$ emissions. The specific goal of the concept is to increase the share of renewable sources in energy consumption by 2 times and achieve the highest indicator in the world - $20 \%$.

The European Union is a major driving force in promoting energy efficiency strategies and combating global climate change. EU takes a comprehensive approach to shaping the legal framework for energy efficiency [14].

The measures, forms and methods of state support in the field of energy saving and energy efficiency applied abroad and provided for by the Russian Energy Saving Program include the following measures:

- Information support of state programs and individual measures to stimulate energy saving

- Tax incentives for energy saving

- Financial support of industrial enterprises in the implementation of energy saving projects

- Application of voluntary agreements between the state and the industrial sector in the field of energy efficiency $[15,16]$.

Thus, the problem of energy saving is urgent and requires a solution. Only coordinated efforts at the federal, regional and local levels will make it possible to implement one of the 
strategically important tasks of the state - to increase energy efficiency and reduce the energy intensity of GDP.

The study was supported by the grant of the President of the Russian Federation for state support of the leading scientific schools of the Russian Federation NSh-2702.2020.6 "Conceptual Foundations of a New Paradigm of Economic Development in the Era of Technological and Social Transformation."

\section{References}

1. United Nations Environment Program. United Nations. Retrieved from: https://www.un.org/ru/ga/unep/

2. Kozhevnikova, T.M., Terakopov, S.G. (2013). «Green economy» as one of the areas of sustainable development. Socio-economic phenomena and processes, 3(49), 78-82.

3. Moore Lappé, F. (2012). Our Challenge - Developing an Eco-Mind. Green economy in action: Articles and Excerpts that Illustrate Green Economy and Sustainable Development Efforts. Retrieved from: https://www.un.org/waterforlifedecade/pdf/green_economy_in_action_eng.pdf

4. Rifkin, J. (2009). The Third Industrial Revolution. Retrieved from: https://archive.org/details/greeneconomicsin00moll

5. Scott Cato, M. (2009). Green Economics: An Introduction to Theory, Policy and Practice. Retrieved from: https://archive.org/details/greeneconomicsin00moll

6. Vertakova, Y.V., Plotnikov V.A. (2019). Assessment of the economic activity greening level and the green economy development directions. In IOP Conference Series: Earth and Environmental Science, 392, Art. No. 012078.

7. Vertakova, Y.V., Plotnikov V.A. (2019). The integrated approach to sustainable development: the case of energy efficiency and solid waste management. International Journal of Energy Economics and Policy, 9(4), 194-201.

8. Vertakova, Y., Plotnikov, V., Babich, T. (2020). Conceptual framework of state economic policy in the technological and social transformation conditions. In $E 3 S \mathrm{Web}$ of Conferences. Topical Problems of Green Architecture, Civil and Environmental Engineering, 164, Art. No. 11016.

9. Zlobina, N., Merkulova, E., Muratova, O., Kondrakov, O., Vertakova, Y. (2019). Impact of energy economy development on the region's population life quality. In E3S Web of Conferences, 110, Art. No. 02106.

10. IEA - International Energy Agency. Retrieved from: https://www.iea.org/

11. Global Energy Review. (2020). The impacts of the Covid-19 crisis on global energy demand and CO2 emissions. Retrieved from: https://www.iea.org/reports/globalenergy-review-2020

12. Forecast of energy development in the world and Russia until 2040. Retrieved from: https://www.eriras.ru/files/forecast_2040.pdf

13. Ignatieva, A.A. (2011). Green Economy: A Practical Vector of Sustainable Development or a Political Compromise? Russia in the World Around, 1, 28-60.

14. Development of a Regional Action Plan and Recommendations on the Formation and Implementation of a Policy in the Field of Energy Efficiency and Energy Saving in the CIS Countries. Retrieved from: https://www.unece.org/fileadmin/DAM/ energy/se/pdfs/ee21/EE21_Subregional_projects/RegionalActionPlanRus_Jan_2014_F inal.pdf 
15. Ferar, G.S., Rastvortsev, A.F., Blagadyreva, A.M. (2012). Methodological approaches to the formation and implementation of regional environmental policy. Issues of state and municipal management, 1, 27-36.

16. Nadanyiova, M., Gajanova, L., Majerova, J. (2020). Green Marketing as a Part of the Socially Responsible Brand's Communication from the Aspect of Generational Stratification. Sustainability, 12(17), Art. No. 7118. 